\title{
Multilingualism and assimilationism in Australia's literacy-related educational policies
}

Andrea C. Schalley ${ }^{*}$, Diana Guillemin and Susana A. Eisenchlas

School of Languages and Linguistics, Griffith University, Australia

\begin{abstract}
Australia is a country of high linguistic diversity, with more than 300 languages spoken. Today 19 percent of the population aged over five years speak a language other than English at home. Against this background, we examine government policies and prominent initiatives developed at national level in the past 30 years to address the challenge of offering 'Literacy for all', in particular focusing on minority language speaking children. Across the examined policies and initiatives, a distinct negative correlation can be observed: the more multilingual Australia has become, the more assimilationist the policies, and the more monolingual the orientation of the society that governments have sought to establish through policy. We argue that to enhance literacy outcomes more generally, this orientation needs to be reversed. We explain why policy understanding and approach need to instead promote the maintenance of home languages and support literacy acquisition in these languages.
\end{abstract}

Keywords: Australia, bilingualism, diversity, literacy policies, minority language, multiculturalism

\section{Introduction - literacy in the Australian context}

The Melbourne Declaration on Educational Goals for Young Australians (MCEETYA 2008) recognises literacy as an essential skill for students in becoming successful learners and as a foundation for success in all learning areas. Success in any learning area depends on being able to use the significant, identifiable and distinctive literacy that is important for learning and representative of the content of that learning area. (ACARA, n.d.)

Literacy in this context can thus be defined as 'more than just being able to read and write; it is the ability to comprehend, interpret, analyze, respond, and interact with the growing variety of complex sources of information' (Sensenbaugh, 1990, p. 2). However, it is generally also acknowledged that reading and writing are foundational skills that need to be mastered to be able to develop strategies to interact successfully with a growing variety of complex information sources, and for this reason reading and writing are given much attention in schools. ${ }^{1}$

But where do Australians stand internationally in regard on literacy skills? The 2011 Progress in International Reading Literacy Study (PIRLS), if taken at face value, revealed that 25 percent of Year 4 students $^{2}$ failed to meet the minimum reading standard for their age, with Australia ranking $27^{\text {th }}$ among the 100 nations ranked and well behind other English speaking nations (Mullis, Martin, Foy, \& Drucker, 2012). For the adult population, the Adult Literacy

\footnotetext{
*Corresponding author. Email: a.schalley@griffith.edu.au
} 
and Life Skills Survey (ALLS) (Australian Bureau of Statistics, 2006), conducted in English, found in 2006 that approximately 7 million Australians aged 15 to 74 years (46 percent) scored below Level 3, which is considered the level needed to meet the complex demands of work and life in modern economies (SCOTESE, 2012). ${ }^{3}$ While this is worrying in itself and appears to have remained stable over recent years (in 2011-12 preliminary results indicate 7.3 million or 44 percent of this cohort at under Level 3), the 2006 survey also found that:

Examining the literacy skills of people whose first language was not English, 36 percent of this group achieved scores at Level 3 or above on the prose scale and 38 percent on the document scale, compared to 54 percent and 53 percent respectively for the general population. (Australian Bureau of Statistics, 2006, p. 13)

In other words, Australians whose first language is not English (in this paper we also refer to them as 'minority language speakers') are considered much more at risk than English L1 speakers of not reaching the required literacy skills to participate effectively in daily life, with the 2006 survey revealing about 64 percent of them below the required level. Minority language speakers constitute a significant share of Australian society. While Australian English is the de facto official language of Australia (though this is not established in the constitution) and the mainstream section of the population is predominantly monolingual (Lo Bianco, 2001, p. 2), the 2011 Census revealed that over 300 languages are spoken in Australian households (Australian Bureau of Statistics, 2012a). According to the census, nearly 19 percent of the population aged over five years speak a language other than English at home, i.e., about one in five Australians is a minority language speaker.

How have Australian policies recognized literacy and literacy outcomes for minority language speakers and what have these policies tried to achieve in practice? In this paper we examine national government policies and prominent initiatives developed over the past 30 years in pursuit of 'Literacy for all' (DEETYA 1998), particularly as they have sought to support literacy acquisition of children who speak minority languages. ${ }^{4}$ We overview and critically evaluate the most important national policies and prominent initiatives over the last 30 years, focusing on whether a trend in policy orientations can be identified. We argue that it can, and we reflect on resulting implications. We explore this policy landscape for trends in orientation, identifying a distinctly negative correlation: the more multilingual Australia has become, the more assimilationist the policies, and the more monolingual the orientation of the society that these policies have sought to establish. We conclude by outlining our vision, which is informed by an alternative understanding of literacy conceptually and in practice. We discuss possibilities to enhance the national (and personal) rewards of Australia's current mutilingualism through effectively reversing policy orientation, to instead promote the maintenance of home languages and support literacy acquisition in these languages.

\section{Language and literacy policies in Australia - the last $\mathbf{3 0}$ years}

The Australian government has endeavored to address language and literacy issues since implementation of the first national policy on languages in 1987 . Over the last 30 years, five crucial policies and prominent initiatives have been tabled and implemented (Table 1). 
Table 1. Overview of Australian literacy policies and prominent initiatives.

\begin{tabular}{|c|c|c|}
\hline $\begin{array}{l}\text { Year } \\
\text { published }\end{array}$ & Title & References \\
\hline 1987 & 'National Policy on Languages (NPL)' & Lo Bianco (1987) \\
\hline 1991 & $\begin{array}{l}\text { 'Australia's Language: The Australian Language \& Literacy } \\
\text { Policy (ALLP)' }\end{array}$ & DEET (1991) \\
\hline 1998 & 'Literacy for all: The Challenge for Australian Schools' & DEETYA (1998) \\
\hline 2005 & 'Teaching Reading' & DEST (2005) \\
\hline 2008 & $\begin{array}{l}\text { 'National Assessment Program - Literacy and Numeracy' } \\
\text { (NAPLAN) }\end{array}$ & COAG (2008) \\
\hline
\end{tabular}

\section{The National Policy on Languages (NPL) (1987)}

The 1987 National Policy on Languages (NPL) (Lo Bianco, 1987) was "the first explicit language policy in Australia and the first multilingual language policy in an English-speaking country" (Lo Bianco \& Slaughter 2009, p. 16). It strongly promoted multiculturalism and multilingualism and aimed to make community languages an integral part of the education of all Australian school children (Clyne, 1991, p. 214), for instance, by offering study of these languages as second languages through formal education pathways. Though it neither defined nor developed conceptual understanding of literacy, the NPL acknowledged the importance of maintaining minority languages and supporting families in fostering early home literacy practices for pre-school children. Funding was recommended for (1) libraries, to purchase community language materials in languages reflecting the composition of the communities they served, (2) tertiary institutions, for introducing and extending community languages to support the training of professionals (Clyne, 1991), and (3) widespread interpreting and translating services, in recognition of the needs of migrants. Multiculturalism in Australia most certainly was seen as a national asset, and policy recognized the diverse linguistic background of children and their varying sociolinguistic contexts. The NLP was, and to this day is still, 'Australia's only languages policy that was based on grassroots initiative and expert research' (Clyne, 2005, p. 155).

Overall, the NPL was progressive and inclusive, valuing community-school partnerships and fostering connections between schools and community organizations (Lo Bianco, 2001, p. 35). However, while admirable in its goals and aspirations, the NPL's success was limited through shortcomings in its implementation. The onus for facilitating programs to integrate literacy learning into all activities fell on primary school teachers and principals, who were also responsible for supporting the maintenance of community languages. However, programs in community languages at primary schools were developed without providing adequate courses in languages at institutions training primary teachers (Clyne, 1991, p. 218). Without sufficient conceptual and practical training, teachers were largely ignorant about acquiring and maintaining language and about their role as teachers in both processes (Clyne, 1991, p. 244). In addition, Ingram (2003) and Suda (2001) attribute the eventual failure of the NPL to the lack of ongoing review, support and funding commitment by both Federal and State governments. ${ }^{5}$

\section{Australia's Language: The Australian Language and Literacy Policy (ALLP) (1991)}


The NPL was superseded only four years later by a new policy, 'Australia's Language: The Australian Language and Literacy Policy (ALLP)'. The ALLP's national goals were to:

1. develop and maintain effective literacy in English to enable all Australians to participate in Australian society;

2. substantially expand and improve the learning of languages other than English;

3. maintain and develop Aboriginal and Torres Strait Islander languages still in transmission, and where appropriate record those that are not; and

4. expand and improve language services provided by interpreters and translators, the print and electronic media and libraries (DEET, 1991, vol. 1, p. 4).

While learning of languages other than English and maintaining Aboriginal and Torres Strait Islander languages were declared goals, maintaining home languages was no longer part of the picture. The ALLP emphasized English much more strongly, and explicitly proclaimed Australian English as Australia's national language. The then Education Minister John Dawkins insisted that for the national language and literacy policy, 'literacy in English for all Australians must be a necessary, if not sufficient, overarching first goal' (Brock, 2001, p. 55).

At the time it was estimated that approximately one (out of 17) million Australian adults had difficulty carrying out everyday literacy tasks (DEET, 1991). Of those, 72 percent $(716,000)$ were of English speaking background and 28 percent $(284,000)$ were of nonEnglish speaking background (DEET, 1991 vol.2, p. 38). While making some investments into school literacy programs, government focused on provision of adult literacy and English as a second language (ESL) classes, aiming to create a literate workforce. Policy focus was on literacy in English for all Australians, marking a shift in priority from pluralism to economic rationalism (Lo Bianco, 2001; Scarino \& Papademetre, 2001; Clyne, 2005; Scarino 2014) - to 'clear economic and employment ends rather than ends of social justice, educational access and personal satisfaction' (Herriman, 1996, p. 52) - and to a view of languages as being spoken in other countries rather than in Australia, i.e., 'a foreigner understanding of languages' (Lo Bianco \& Slaughter, 2009, p. 22).

Many observers saw that the singular term 'language' in the policy title represented this change of emphasis away from multiligualism, especially when the Education Minister later expressed 'the view that Australia was a monolingual society' (Brock, 2001, p. 62). The focus was no longer on the 'languages' of Australia, but on the 'language' of Australia, Australian English, with particular implications for ESL learners and literacy acquisition.

\section{Literacy for All: The Challenge for Australian Schools (1998)}

The national policy that followed seven years later narrowed the focus even further than the ALLP. The stated goal of "'Literacy for all": The Challenge for Australian Schools' (DEETYA, 1998) was that 'every child leaving primary school should be numerate and able to read, write and spell at an appropriate level' (DEETYA, 1998, p. 9). 'Literacy' - equated to English language literacy - was the declared language goal, to the exclusion of learning and maintaining other languages spoken in Australia. Further, as Edwards and Potts observed, 'In this policy, literacy appears to be a discrete concept or set of skills, rather than being integrally connected to language' $(2008$, p. 128). Moreover, the policy was, as its subtitle 
signaled, explicitly a policy for Australian schools, i.e., adult literacy and any literacy teaching and learning outside formal schooling (e.g., in community settings) were absent from this policy. The policy's main concerns related to (1) development of benchmarks for Years 3, 5, 7, and 9; (2) assessment of all children's achievement against these benchmarks; (3) early intervention where necessary; and (4) reporting on student achievement against benchmarks. In terms of actual support (in this case through early intervention in English language learning), the 'Literacy for all' policy targeted students assessed as being at risk, having difficulties and needing intervention; it was deemed essential that Australian schools ensured no child would fall dangerously behind their peer group (DEETYA, 1998). Overwhelmingly, however, the policy's emphasis was clearly on standards, measuring, evaluation, and assessing achievements. This policy was interested only in the lower end of these achievements, focusing on the minimal 'appropriate' level and on cases where this was not attained (cf. Hammond, 1999, 2001).

As for students with first language other than English, the 1996 National School English Literacy Survey results had indicated that 'approximately one third of Year 3 and Year 5 students from languages other than English backgrounds failed to meet the accepted standard in writing' (Masters \& Forster, 1997, p. 20), and even fewer met the accepted standard in reading. On average, these students were assessed as having lower English literacy levels than students from English-speaking backgrounds (ACER 1997, p. 20), and thus were classified as 'at risk' children. Non-English speaking background was considered to be one of several major factors that place educational outcomes at risk (DEETYA 1998). Yet, while the policy acknowledged that for these students learning literacy in English involves learning a second language (DEETYA 1998), the policy did not make specific provisions for them. Although the policy discusses McKay et al.'s (1997) study that indicated 'bilingualism should be viewed positively both for individuals and for schools, to be used as a resource where possible in the development of L2 literacy' (McKay et al., 1997, p. 185), the policy did not apply this thinking in strategy or practice. Early intervention meant only intervention in English, not taking into account the specific circumstances and linguistic environments in which children grew up.

Issues with the benchmarking process as such have also been raised. Davison (1999) highlighted some of the flaws in the benchmark process because 'the benchmarks describe features of literacy typical of Australian-born mother-tongue speakers of English' (Davison, 1999, p. 68). She saw the need for a complementary but distinctive set of benchmarks for ESL learners at different stages of schooling, as diversity rather than commonality is the norm in Australian schools (Davidson, 1999). The practice of benchmarking served only to 'improve educational planning and public accountability, rather than to address individual student achievement' (1999, p. 67), and therefore most of the concerns and processes presented in the policy could not have been and indeed have not been efficient in pursuing the policy's stated goal of improving 'literacy for all'. As Cross (2009, p. 514) noted, 'the framework privilege[d] those who already come to schools having the "right" identity: the "right" social networks, the "right" cultural background, the "right" linguistic capital.'

The 'Literacy for all' policy (DEETYA, 1998) is the most recent policy ('white paper') on literacy published by an Australian federal government. ${ }^{6}$ Further reports and programs have been delivered, but no government has ventured into developing a replacement for what is 
now a 16-year old policy. Although they are not policies per se, two government initiatives Teaching reading (2005) and The National Assessment Program - Literacy and Numeracy (NAPLAN) (2008) are significant for our discussion.

\section{Teaching reading (2005)}

In 2004, the Australian Government launched a 'National Inquiry into the Teaching of Literacy', in response to an open letter written signed by 26 Australian psychologists and reading researchers, who expressed their concerns about how reading is typically taught in Australian schools (DEST, 2005, p. 2). The Education Minister asked the Committee to inquire into (1) the teaching of reading in Australian schools; (2) the assessment of reading proficiency, including identifying children with reading difficulties; and (3) teacher education and the extent to which it prepares teachers for reading instruction (DEST, 2005, p. 3). This emphasized not only reading (while disregarding other literacy skills), but also more specifically the teaching (but not learning) of literacy. This emphasis was articulated in the title of the ensuing report, 'Teaching reading: Report and recommendations' (DEST 2005; also referred to as the 'Rowe report'), which concentrated on reading and its teaching, and to a large extent discussed whether the whole language and the phonics approach is better.

The report thus narrowed down even further the area of interest concerning literacy. Its recommendations mostly targeted teachers (e.g., literacy should be the responsibility of all teachers across the curriculum) and the formal schooling context (e.g., education authorities and schools should be responsible for the measurement of individual progress in literacy by regularly monitoring the development of each child). The only recommendation that went somewhat beyond this was Recommendation 4:

The Committee recommends that programs, guides and workshops be provided for parents and carers to support their children's literacy development. These should acknowledge and build on the language and literacy that children learn in their homes and communities. (DEST, 2005, p. 15)

The report thus acknowledged that children's home language is an important foundation on which to build literacy learning, and moreover recognized 'considerable diversity in the life experiences of children in Australian schools' (DEST, 2005, p. 1), including students who have arrived recently in Australia and other students from non-English speaking backgrounds. Nonetheless, Recommendation 4 was also the only recommendation that addressed the special needs of children speaking minority languages and even then suggested no initiatives for these students.

In light of the 'Literacy for all' policy with its narrow focus on benchmarking and assessment, it is not surprising that in the 'Teaching reading' report, on the matter of literacy only the recommendations relating to literacy assessment were observed. ${ }^{7}$ For minority language speaking children this raises the same issues as before. Indeed, the report made no progress in Australia's approach to supporting literacy development of minority language speaking children. But it showcases the direction of the national literacy debate in Australia. The last program we discuss here makes this even more apparent. 


\section{The National Assessment Program - Literacy and Numeracy (NAPLAN) (2008)}

In 2008, the 'National Partnership Agreement on Literacy' (COAG, 2008) was formed between the Commonwealth Government and the Australian States and Territories. It allocated AU\$577.4 million over four years to deliver a 'National Action Plan for Literacy and Numeracy' (COAG, 2008). The main pillar has been the 'National Assessment Program Literacy and Numeracy' (NAPLAN) testing students of Years 3, 5, 7, and 9 in reading, writing, language conventions (spelling, grammar and punctuation) and numeracy since 2008 as an annual nation-wide assessment. On 'reward payments' to States and Territories, the National Action Plan explains, 'Reading is used as the proxy for Literacy' (COAG, 2008, p. 12). With literacy in this proxy position, distributing funding based on achievement of targets continues to reduce literacy in practice to reading, the most basic skill, and more solidly codifies the narrow understanding of literacy that was earlier embedded in the 'Teaching reading' report.

The goals of the Agreement reiterate a number of points that were identified in the 'Literacy for all' policy (DEETYA, 1998) and the 'Teaching reading' report (DEST 2005), including (1) to improve the literacy outcomes of all students, with a priority focus on primary school aged students most in need of support, (2) to identify and implement intervention strategies that will improve literacy outcomes, and (3) to identify and address the needs of students from diverse backgrounds (COAG, 2008). Retaining 'assessment', 'reporting', and 'intervention' as important keywords helps to continue the narrow understanding of literacy in NAPLAN. Even more emphasis is placed on the assessment and reporting of achievements, which are now explicitly institutionalized through the allocation of resources. ${ }^{8}$

NAPLAN surely presents a 'high stakes' test, i.e., with important ramifications for test taker, teacher and school. As such, it has been criticized for its negative impacts on people - anxiety and stress for students and teachers and self-esteem problems for student - and for inimically narrowing the curriculum (Polesel, Dulfer, \& Turnbull, 2012; cf. Paris, 2000; Paris \& McEvoy, 2000). Beyond this is the less visible, longer term efficacy. High stakes tests are generally found to be highly counterproductive as they 'can structure the educational experiences of students in ways that limit the development of the range of skills and literacies needed in the modern world, encouraging low-level thinking and promoting outcome measures rather than the intrinsic processes of learning and acquiring knowledge' (Polesel, Dulfer, \& Turnbull, 2012, p. 5). In sum, what emerge consistently are:

serious concerns regarding the impact of high stakes testing on student health and well-being, learning, teaching and curriculum. Although much of the literature is focussed on the USA and the UK, the consistency of these findings raises legitimate questions and deep concern regarding the Australian experience. (Polesel, Dulfer, \& Turnbull, 2012: 5)

NAPLAN's reliability and validity are also dubious. Informed observers generally see that high stakes testing does not provide effective measurement of an individual's learning, and its usefulness as a diagnostic tool for teachers is limited (Paris, 2000). Surveys of school 
principals and teachers in Australia support this view. The most recent survey in 2013 revealed only about one third of respondents said the test results had been useful as a diagnostic tool (Independent Education Union, 2013, p. 9; for 2010 data cf. Athanasou, 2010).

All of these shortcomings of NAPLAN are aggravated when it comes to minority-language speaking children. ${ }^{9}$ The Australian Council of TESOL Associations identified how 'test questions often contain biased assumptions that test takers are Anglo-Australian urban dwellers who are fluent users of Standard Australian English as appropriate to their age and school level' (ACTA, 2013: 5). This, possibly compounded by poor performance due to linguistic barriers, can easily lead minority-language speaking children to loss of selfconfidence and self-esteem and potentially to mental and physical health problems (ACTA, 2013). The report of the Senate Standing Committee on Education and Employment on the effectiveness or otherwise of NAPLAN recognized some of these issues and recommended that the needs of students with a non-English speaking background be taken into account when designing adaptive testing for NAPLAN Online (SSCEE, 2014). Nevertheless, given this Standing Committee's footing within the architecture of government, its report did not question the conceptual and methodological underpinnings of the Program, including the conception of literacy in which the Program is rooted. The relative light weight of nonEnglish speakers as a constituency on the national electoral landscape may also help explain this response.

In our view, both NAPLAN and the Standing Committee's report on it represent a poorly informed, narrow minded and impoverished approach to literacy education. Detrimental effects for the nation are not just the academic, but also involve the socio-cultural, economic and strategic benefits that the nation and its citizens forsake by not promoting the maintenance of home languages and supporting students' literacy acquisition in these home languages.

\section{A negative correlation: Implications}

Our examination of the literacy-related national policies and major initiatives of the Australian Government over the last 30 years reveals a clear trend. We identify continuous progressive narrowing of both the objectives and areas of interest set out in these documents, alongside and consistent with the values they represent. ${ }^{10}$

In the 1970s and 1980s, federal government generally fostered recognition of Australian society as comfortably pluralistic and supportive of cultural and linguistic diversity (Clyne, 2005). Accordingly, the national government's first literacy-related policy from 1987, the National Policy on Languages (NPL), promoted multilingualism. Home language maintenance was one of the objectives expressed clearly in the document. However, the next policy statement, articulated in the white paper 'Australia's Language: The Australian Language and Literacy Policy' (ALLP) only four years later, narrowed understanding of the nation's languages from many to just one, English as the 'national' language of Australia, and with it promoted the need to acquire English literacy exclusively. In 1998, announcement of the new policy 'Literacy for all: The Challenge for Australian Schools' introduced the new approach treating literacy separately from language, with attention 
exclusively on 'literacy' as a much more narrowly defined field and equated with 'English literacy'.

Since this policy - which was also the last literacy policy presented in Australia - language diversity has been and continues to be perceived as problematic and indeed contributing to lower English literacy levels. Subsequent prominent literacy initiatives have focused only on the school context, disregarding all other avenues of literacy (and language) acquisition. The 'Teaching Reading' report from 2005 not only continues to treat literacy as a discrete concept distinct from language, but further restricts understanding of what literacy is and what the important literacy skills are to exclusively the reading skill. This report places even more onus on teachers and schools, focusing only on the teaching, and not on the learning, of reading. Finally, the most recent initiative makes assessment and reporting the focal point. The 'National Assessment Program - Literacy and Numeracy' (NAPLAN, 2008) further downgrades Australia's efforts in literacy education by concentrating exclusively on assessing and reporting literacy 'outcomes' at the expense of teaching literacy per se.

We view this unexplained and unjustified 'narrowing' of literacy, conceptually and in practice, as a regressive trend. It is well reflected in the policy titles, as we see in Figure 1 listing the keyword of each of the documents' policy titles. It shows that Australian governments have moved the nation from supporting many languages to supporting only one national language (English), literacy in this one language, reading as the one highlighted skill for literacy, and assessment of English literacy as the nation's foremost literacy aim.

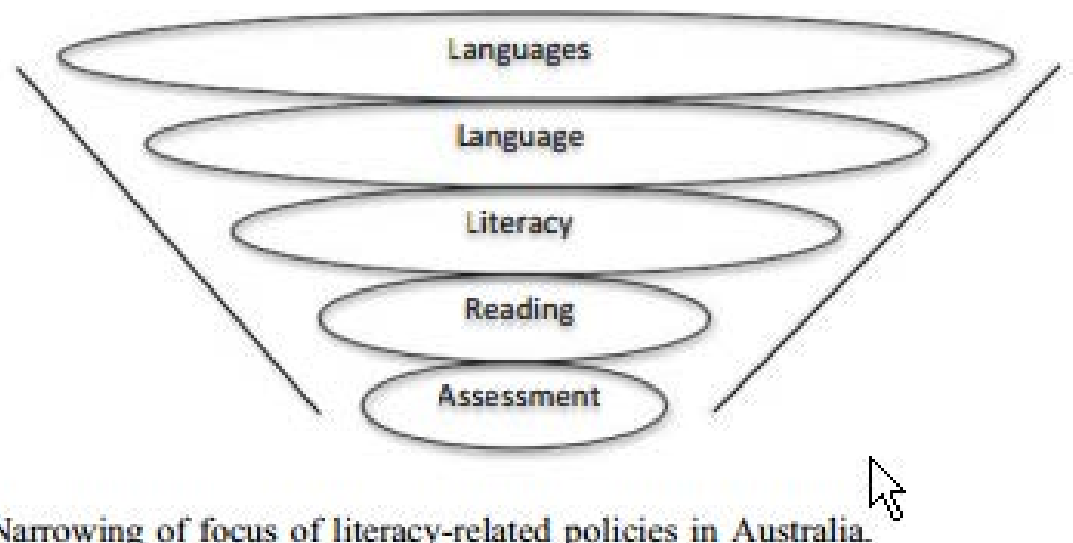

Figure 1. Narrowing of focus of literacy-related policies in Australia.

We can only agree with Cross's criticism of this 'reductionist' trend in the 'Literacy for all' policy:

With a focus on accountability, neo-liberalism has reduced literacy to an inventory of skills comprising little more than the sum of its parts (e.g., sounding out words, reading quickly, filling in the blanks, etc.). In so doing, it offers a framework for literacy that can be easily managed, measured and monitored to provide accountability for the core 'business of schooling'; in this case, the 'production' of literacy 'outcomes'. The cost of efficiency, however, has been a 'reductionist', stripped-back model of literacy (Davison, 2001). Indeed, if literacy is our 'ticket of entry' into society, then it has to be asked if a highly manageable ('testable') - but extremely impoverished ('basic') model of literacy is of value? [sic] (Cross, 2009, p. 514). 
In the context of minority-language speaking children, the narrowing trend in policy runs counter to a widening trend in the composition of Australian society: The number of people who speak a language other than English at home is still increasing. Rising from 14 percent in 1986 (one person in every seven; Castles, 1988, p. 16) to 19 percent in 2011 (one person in every five; Australian Bureau of Statistics 2012b), the increase is more than a third across these 25 years. Similarly the number of languages other than English spoken at home in Australia has increased dramatically over the same time-frame. Castles (1993, p. 13) reported 68 languages in 1991, while the Australian Bureau of Statistics (2013) reported over 300. In this light we identify a distinct negative correlation: the more multilingual Australian society has become, the more assimilationist the policies and the more monolingual the orientation of the society politicians envisage and pursue. ${ }^{11}$ Cross (2009) explains this negative correlation evident in the shift to a facile model of literacy as a government ploy to generate social stability and maintain social cohesion. He sees it has been a conventional strategy of national governments to mandate a universal basal approach to language policy in the face of changing social, linguistic and cultural conditions, regardless of the cultural and linguistic background of the nation's children. He explains that a "focus on "teaching the basics" within schools also maintains the existing distribution of power, knowledge and skills within society more broadly' (Cross, 2009, p. 514). Put more bluntly, government pushing of monolingualism and monoliteracy is not primarily to serve education aims, but to help maintain the current distribution of power, knowledge and skills that primarily benefits the ruling class.

Whether or not one agrees with Cross's perspective, there is clearly disjunction between what the research reveals and what the policies recommend (Hammond, 2001; see also Cahill, 1996; Gibbons \& Ramirez, 2004; Moore, 2001). The policies outline or at least point to current state of the art knowledge and best practice in the field - and therefore always mention something about recognizing the diversity of the population and the need to cater for non-English speaking background students. But this appears to be tokenistic, with no influence on recommendations or guidelines. Only the first National Policy on Languages in 1987 differed in this respect, with its recommendations informed by solid conceptual and practical knowledge of the field and its best practices. The policy was developed through a grassroots approach with extensive community consultations and input from scholars across Australia (Clyne, 2005). The circumstances of its creation led to the most ambitious and visionary policy, propelling Australia to the forefront of literacy policy development at the time. In sharp contrast to this, Australia now has to deal with the consequences of the topdown development of recent initiatives including NAPLAN, short-sighted initiatives that center on assessment to meet the accountability measures that policymakers now seek to ensure.

There is no need to question the value of being literate in English in Australia, and acquiring English literacy is most certainly a crucial goal of the Australian education system. Yet two pertinent issues need to be considered in the Australian context.

First, pushing English literacy to the exclusion of literacy in other languages results in lost opportunities for the country and will have detrimental effects for the children, families and communities. We know now that insufficient support for minority languages 'deprives children of the recognized educational, social, and affective advantages associated with 
bilingualism and can hinder intergenerational cohesion within families and communities' (Eisenchlas et al., 2013, p. 2; cf. also the references listed therein). This also applies to literacy support for minority languages, as reading and in particular writing are fragile skills generally not needed in the daily life of minority speakers, but requiring regular practice for their maintenance. In addition, Wright and Taylor (1995, p. 241) have shown that 'early heritage language education can have a positive effect on the personal and collective selfesteem of minority language students', and students' self-esteem is an important determinant of academic success (Cummins, 2001; Makin et al., 1995; Wright \& Taylor, 1995). Furthermore, lack of literacy acquisition in minority languages where it is possible results in loss of a wealth of language knowledge and abilities that a nation could draw upon as needed, for example, in its international economic and diplomatic efforts. Australia's assimilationist approaches outlined above appear to be based on the belief that an Englishonly approach improves social integration with the host country. Yet evidence suggests that integration is achieved more effectively when a person's own background is valued, since 'conflict and division arise not out of difference, but rather out of denial of the right and opportunity to be different' (Smolicz, 1981, p. 64).

Second, it is highly questionable whether the best path for students to achieve English literacy is to immerse them in English only and to support their development of English and its literacy to the exclusion of their minority language. This thinking is based on a false belief that early entry into English language education makes it easier for minority language students to be integrated in the majority culture and thus improve their chances of competing in mainstream society. However, as already famous from a 1953 UNESCO report, 'it is axiomatic that the best medium for teaching a child is his (sic) mother tongue' (UNESCO, 1953, p.11). There is ample evidence that literacy acquisition in the home language enhances, rather than detracts from, literacy acquisition in the majority language (Eisenchlas et al., 2013). Significant here, the type of writing system is irrelevant, as literacy skills are transferable and 'there is high correlation between native language and secondlanguage literacy ability even with languages of dissimilar writing system[s]' (Brisk \& Harrington, 2010: xiv; cf. also Bialystok et al., 2005).

\section{'Literacy for all': A way forward}

Against this background and the research results outlined above, Australia needs to turn the tide - it needs to become visionary again, to take research results seriously, and listen to people at grassroots level. Certainly there is now a vast number of languages to be supported (many more than in 1987), and the formal education system is unlikely to be able to systematically support them all. Another challenge is naturally posed by the varying levels of minority language proficiency, levels of literacy, differences in motivation and tightness of the community bonds of the children involved. Notwithstanding this, we believe that these challenges are no reason to lower ambition, but rather to try to become more innovative and 'think big'.

Our vision is to create a free educational platform that enables the tailored and individualized acquisition of literacy in diverse languages (for a similar example targeting other learning areas, see the Khan Academy, https://www.khanacademy.org/about). New information technologies enable tailoring of educational experiences to each child's 
circumstances. To achieve success, communities and researchers need to work together, to create resources and guided learning experiences that are simultaneously challenging, engaging and culturally appropriate for the child. While this has never before been tried with the aim of supporting the development of minority language literacy, we have carried out a number of promising related projects (see Eisenchlas et al., 2013, for an overview of some). ${ }^{12}$ We would like to build on these efforts and engage society from the grassroots. Such an approach would enable us to offer early literacy instruction in a child's minority language (before or simultaneous with English literacy in school), and take into account the benefits of family and community involvement in children's literacy learning that have been shown to contribute to improved literacy outcomes for large numbers of children (Cairney et al., 1995). In this context, it will be extremely helpful if new policies are devised that promote the maintenance of home languages and support literacy acquisition in minority languages.

We are aware that this is a bold vision, one that requires Australian society to embrace its multiculturalism (in contrast to what the current government is suggesting; see Morrison, 2013). The benefits of multilingualism need to be communicated more clearly to all levels of society. We hope that together we will be able to convince educators, communities and families that trialing this approach is a worthwhile innovative enterprise, one that will not only benefit individuals and families but also help advance Australia as a nation.

\section{References}

(AACLAME) Australian Advisory Council on Languages and Multicultural Education. (1990). The National Policy on Languages: December, 1987-March, 1990. Report to the Minister for Employment, Education and Training. Canberra, ACT: Australian Advisory Council on Languages and Multicultural Education.

(ACARA) Australian Curriculum, Assessment and Reporting Authority. (n.d.). Literacy. http://www.australiancurriculum.edu.au/GeneralCapabilities/Literacy

(ACER) Australian Council for Educational Research. (1997). Mapping literacy achievement. Results of the 1996 National School English Literacy Survey. Camberwell, VIC: Australian Council for Educational Research (ACER).

(ACTA) Australian Council of TESOL Associations. (2013). Submission 79 to the Senate inquiry into the effectiveness of the National Assessment Program - Literacy and Numeracy. http://www.aph.gov.au/DocumentStore.ashx?id=b9acd933-f802-4a1d-b6806106b97699e3\&subld=11624

Athanasou, J. (2010). NAPLAN and MySchool survey. Barton, ACT: Independent Education Union of Australia.

Australian Bureau of Statistics. (2006). Adult Literacy and Life Skills Survey, summary results Australia.

http://www.tach.asn.au/documents/ABS2006LiteracyandLifeskillsSurvey.pdf

Australian Bureau of Statistics. (2012a). 2011 Census shows Asian languages on the rise in Australian households. [National Media Release]. Canberra, ACT: Australian Bureau of Statistics. http://www.abs.gov.au/websitedbs/censushome.nsf/home/CO-60

Australian Bureau of Statistics. (2012b). 2071.0 - Reflecting a nation: Stories from the 2011 Census, 2012-2013. http://www.abs.gov.au/ausstats/abs@.nsf/mf/2071.0

Australian Bureau of Statistics. (2013). 4102.0 - Australian social trends: The 'average' Australian. 
http://www.abs.gov.au/AUSSTATS/abs@.nsf/Lookup/4102.0Main+Features30April+ 2013\#back3

Bialystok, E., Luk, G. \& Kwan, E. (2005). Bilingualism, biliteracy, and learning to read: Interactions among languages and writing systems. Scientific Studies of Reading, 9, 43-61.

Brisk, M.E. \& Harrington, M.M. (2010). Literacy and bilingualism. A handbook for ALL teachers. Mahwah, NJ: Lawrence Erlbaum.

Brock, P. (2001). Australia's language. In J. Lo Bianco \& R. Wickert (Eds.) Australian policy activism in language and literacy (pp. 47-74). Melbourne, VIC: Language Australia.

Cahill, D. (1996). Immigration and schooling in the 1990s. Canberra: Australian Government Publishing Service.

Cairney, T.H., Ruge, J., Buchanan, J., Lowe, K. \& Munsie, L. (1995). Developing partnership: The home, school and community interface, Vol. 1 - Summary of findings and recommendations. Sydney, NSW: University of Western Sydney Nepean.

Castles, I. (1988). Census of population and housing, 30 June 1986. Census 86 - Australia in profile, a summary of major findings. Canberra, ACT: Australian Bureau of Statistics. http://www.ausstats.abs.gov.au/ausstats/free.nsf/0/0D42204C00A51765CA2574CE0 015DD7C/\$File/25020 1986 Australia in Profile.pdf

Castles, I. (1993). Census of population and housing 6 August 1991. Australia in profile. Canberra, ACT: Australian Bureau of Statistics.

http://www.ausstats.abs.gov.au/ausstats/free.nsf/0/4C64DE2D65803F30CA2574BF0 0167A44/\$File/28210 1991230 Australia in Profile.pdf

Chiro, G. (2014). Cultural and linguistic diversity in Australia: navigating between the Scylla of nationhood and the Charybdis of globalisation. International Journal of Multilingualism, 11(3), 334-346.

Clyne, M. (1991). Community languages. The Australian experience. Cambridge: Cambridge University Press.

Clyne, M. (2005). Australia's language potential. Sydney: University of New South Wales Press.

(COAG) Council of Australian Governments. (2008). National Partnership Agreement on Literacy and Numeracy (NAPLAN). http://www.federalfinancialrelations.gov.au/content/npa/education/smarter schoo Is/literacy numeracy/national partnership.pdf

Commonwealth of Australia. (2012). Australia in the Asian century. White Paper, October 2012. Canberra, ACT: Commonwealth of Australia. http://pandora.nla.gov.au/pan/133850/20130914-

0122/asiancentury.dpmc.gov.au/sites/default/files/white-paper/australia-in-theasian-century-white-paper.pdf

Cross, R. (2009). Literacy for All: Quality language education for few. Language and Education, 23(6), pp. 509-522.

Cummins, J. (2001). Negotiating identities: Education for empowerment in a diverse society. Los Angeles, CA: California Association for Bilingual Education.

Davison, C. (1999). Missing the mark: The problem with the benchmarking of ESL students in Australian schools. Prospect, 14(20), pp. 66-76.

Davison, C. (2001). Current policies, programs and practices in school ESL. In B. Mohan, C. Leung, \& C. Davison (Eds.) English as a second language in the mainstream: Teaching, learning and identity (pp. 30-50). London, UK: Longman Pearson. 
(DEET) Department of Employment, Education and Training. (1991). Australia's language: The Australian language and literacy policy. 2 vols: Vol. 1: Policy information paper (White Paper); Vol. 2: Companion volume to the policy paper. Canberra, ACT: Australian Government Publishing Service.

(DEETYA) Department of Employment, Education, Training and Youth Affairs. (1998). Literacy for all: The challenge for Australian schools. Commonwealth literacy policies for Australian schools. Australian schooling monograph series. Canberra, ACT: DEETYA.

(DEST) Department of Education, Science and Training. (2005). Teaching reading. Report and recommendations of the National Inquiry into the Teaching of Literacy. Canberra, ACT: Department of Education, Science and Training.

Devlin, B. (2009). Bilingual education in the Northern Territory and the continuing debate over its effectiveness and value. Paper presented at the AIATSIS Research Symposium, "Bilingual Education in the Northern Territory: Principles, policy and practice".

http://www.abc.net.au/4corners/special eds/20090914/language/docs/Devlin pap er.pdf

Dickson, G. (2012a). No Warlpiri, no school? A preliminary look at attendance in Warlpiri schools since introducing the First Four Hours of English policy. Ngoonjook: A Journal of Australian Indigenous Issues, 35, 97-113.

Dickson, G. (2012b, July 11). Ngurrju! Manymak! Pupuni! NT drops first four hours in English policy. Crikey Daily Mail. http://blogs.crikey.com.au/fullysic/2012/07/11/ngurrjumanymak-pupuni-nt-drops-first-four-hours-in-english-policy/

Edwards, D. \& Potts, A. (2008). What is literacy? Thirty years of Australia literacy debates (1975-2005). Pedagogia Historia, 44(1-2), pp. 123-135.

Eisenchlas, S.A., Schalley, A.C. \& Guillemin, D. (2013). The importance of literacy in the home language: The view from Australia. SAGE Open, October-December 2013: 114. DOI: $10.1177 / 2158244013507270$. http://sgo.sagepub.com/content/3/4/2158244013507270

Eisenchlas, S.A., Schalley, A.C. \& Moyes, G. (in preparation). Play to learn: Self-directed literacy acquisition through online games.

Ferrari, J. (2012). A decade of lost action on literacy. The Australian, 22 December. http://www.theaustralian.com.au/national-affairs/a-decade-of-lost-action-onliteracy/story-fn59niix-1226542150781\#

Gibbons, J. \& Ramirez, E. (2004). Different beliefs: Beliefs and the maintenance of a minority language. Journal of Language and Social Psychology, 23(1), pp. 99-117.

Hage, G. (1998). White Nation: Fantasies of white supremacy in a multicultural society. Annandale, NSW: Pluto.

Hammond, J. (1999). Literacy crises and ESL education. Australian Journal of Language and Literacy, 22(2), pp. 120-134.

Hammond, J. (2001). Literacies in school education in Australia: Disjunctions between policy and research. Language and Education, 15(2-3), pp. 162-177.

Herriman, M. (1996). Language policy in Australia. In M. Herrimann \& B. Burnaby (Eds.), Language policies in English-dominant countries (pp. 35-61). Clevedon: Multilingual Matters.

Independent Education Union of Australia. (2013.) Submission 41 to the Senate inquiry into the effectiveness of the National Assessment Program - Literacy and Numeracy. 
http://www.aph.gov.au/DocumentStore.ashx?id=f5fe6f22-5873-41fe-966f-

587149e5c0f7\&subld=11572

Ingram, D. E. (2003). English language policy in Australia. Brisbane, QLD: Griffith University, Centre for Applied Languages and Linguistics.

Lo Bianco, J. (1987). National Policy on Languages. Canberra, ACT: Australian Government Publishing Service.

Lo Bianco, J. (2001). From policy to anti-policy: How fear of language rights took policymaking out of community hands. In J. Lo Bianco \& R. Wickert (Eds.) Australian policy activism in language and literacy (pp. 13-44). Melbourne, VIC: Language Australia.

Lo Bianco, J. \& Slaughter, Y. (2009). Second languages and Australian schooling. [Australian Education Review 54]. Camberwell, VIC: Australian Council for Educational Research (ACER).

Makin, L., Campbell, J., \& Jones Diaz, C. (1995). One childhood, many languages: Guidelines for early childhood education in Australia. Pymble, NSW: Harper Educational.

Martín, M.D. (2008). Advice to speak English in Australia, Ethnicities, 8, 68-101.

Masters, G. \& Forster, M. (1997). Literacy standards in Australia. Camberwell, VIC: Australian Council for Educational Research (ACER).

(MCEETYA) Ministerial Council on Education, Employment, Training and Youth Affairs. (2005). National Statement and Plan for Languages Education in Australian Schools 2005-2008.

http://www.mceetya.edu.au/verve/ resources/languageeducation file.pdf

(MCEETYA) Ministerial Council on Education, Employment, Training and Youth Affairs. (2008). Melbourne Declaration on Educational Goals for Young Australians. http://www.mceecdya.edu.au/verve/ resources/national declaration on the educ ational goals for young australians.pdf

McKay, P., Davies, A., Devlin, B., Clayton, J., Oliver, R., \& Zammitt, S. (1997). The Bilingual Interface Project. The relationship between first language development and second language acquisition as students begin learning English in the context of schooling. Canberra, ACT: Department of Employment, Education, Training and Youth Affairs.

Moore, H. (2001). Although it wasn't broken, it certainly was fixed: Interventions in the Australian Migrant English Program 1991-1996. In J. Lo Bianco \& R. Wickert (Eds.) Australian policy activism in language and literacy (pp. 93-120). Melbourne, VIC: Language Australia.

Morrison, S. (2013). Speech delivered to the Menzies Centre for Australian Studies at Kings College, London, United Kingdom, January 2013. http://australianpolitics.com/2013/01/24/scott-morrison-australia-land-of-ouradoption.html

Mullis, I. V. S., Martin, M. O, Foy, P. \& Drucker, K. T. (2012). PIRLS 2011 International Results in Reading. Chestnut Hill, Mass: TIMSS \& International Study Center, Lynch School of Education, Boston College. http://timssandpirls.bc.edu/pirls2011/downloads/P11 IR FullBook.pdf

Murphy, E. (2012, August 15). NT government quietly abandons bilingual ban. Tracker. http://tracker.org.au/2012/08/nt-government-quietly-abandons-bilingual-ban/

Paris, S. (2000). Trojan horse in the schoolyard: The hidden threats in high stakes testing. Issues in Education, 6(1/2), pp. 1-8.

Paris, S. \& McEvoy, A. (2000). Harmful and enduring effects of high stakes testing. Issues in Education, 6 (1/2), pp. 145-160. 
Polesel, J., Dulfer, N. \& Turnbull, M. (2012). The experience of education: The impacts of high stakes testing on school students and their families. Literature Review. Sydney: Whitlam Institute within the University of Western Sydney.

(QDETE) Queensland Department of Education, Training and Employment. (2014). Great Results Guarantee. http://education.qld.gov.au/schools/grants/resources/greatresults-guarantee.pdf

Scarino, A. (2014). Situating the challenges in current languages education policy in Australia-unlearning monolingualism. International Journal of Multilingualism, 11(3), 289-306.

Scarino, A. \& Papademetre, L. (2001). Ideologies, languages, policies: Australia's ambivalent relationship with learning to communicate in 'other' languages. In J. Lo Bianco \& R. Wickert (Eds.) Australian policy activism in language and literacy (pp. 305-323). Melbourne, VIC: Language Australia.

(SCOTESE) Standing Council on Tertiary Education Skills \& Employment. (2012). National Foundation Skills Strategy for http://www.scotese.natese.gov.au/ data/assets/pdf file/0007/71755/National Fo undation Skills Strategy for Adults.pdf

Sensenbaugh, R. (1990). Multiplicities of literacies in the 1990s. ERIC digest. Bloomington, Indiana: ERIC Clearinghouse on Reading and Communication Skills. http://files.eric.ed.gov/fulltext/ED320138.pdf

Smolicz, J. J. (1981). Culture, ethnicity and education: Multiculturalism in a plural society. In: J. Megarry, S. Nisbet and E. Hoyle (Eds.) World Year Book of Education (pp. 17-36). London and New York: Kogan Page.

(SRCEEWR) Senate References Committee on Education, Employment \& Workplace Relations. (2010). Administration and reporting of NAPLAN testing. Canberra, ACT: Senate Printing Unit, Parliament House.

(SSCEE) Senate Standing Committee on Education and Employment. (2014). Effectiveness of the National Assessment Program - literacy and numeracy. Final report. Canberra, ACT: Senate Printing Unit, Parliament House.

Suda, L. (2001). Policies and pedagogies for lifelong literacy: International perspectives for the $21^{\text {st }}$ century. Melbourne, VIC: Language Australia. (Research report conducted for the Adult Literacy and Numeracy Australian Research Consortium [ALNARC]).

(UNESCO) United Nations Educational, Scientific and Cultural Organization. (1953). The use of vernacular languages in education. [Monographs on Fundamental Education]. Paris: UNESCO.

Wright, S.C. \& Taylor, D.M. (1995). Identity and the language of the classroom: Investigating the impact of heritage versus second-language instruction on personal and collective self- esteem. Journal of Educational Psychology, 87, 241-252.

\footnotetext{
Notes

${ }^{1}$ For instance, schools make literacy their 'learning focus'; cf. 'This year we will again make Reading and Writing the improvement agenda for the school.' (Newsletter, Robertson State School, Brisbane, Queensland; 30 January 2014)

${ }^{2}$ Australian Year (class) levels correspond roughly to those in the US, i.e., Year 1 corresponds to Grade 1 in the US (children aged 6-7 years), Year 4 corresponds to Grade 4 in the US (children aged 9-10 years).
} 
${ }^{3}$ In the ALLS, proficiency was measured on a scale ranging from 0 to 500 points. The resulting continuous scores were grouped into five skill levels, with Level 1 being the lowest measured level of literacy. For a more detailed description of the levels, see SCOTESE (2012: 26-28).

${ }^{4}$ Those who speak a language other than English at home include 53 percent of first generation Australians, 20 percent of second generation Australians, and only 1.6 percent of the third-plus generation (Australian Bureau of Statistics 2012a). These declining percentages provide evidence of a language shift away from first languages towards English only, which constitutes a loss of opportunities for the country (Eisenchlas et al., 2013).

${ }^{5}$ Brock (2001: 58) observed of the funding for the NLP and the ALLP policy that superseded it (section 2.2): "Although doubt is expressed in the report about the accuracy of the [NLP] figures, outlays for the years had been as follows: 1987-88 - \$15 million; 1988-89 - \$28.65 million; 1988-89 [sic!] - \$27.3 million; 1990-91 $\$ 23$ million (AACLAME 1990: 2). [...] In striking contrast, the magnitude of difference in scope between the NPL and ALLP can be illustrated by the four year figures of the latter's implementation: 1991-92 - \$278.46 million; 1992-93 - \$350.51 million; 1993-94 - \$333.33 million." According to these figures, the NLP (with \$93.95 million) received only about 10 percent of what the ALLP received (with $\$ 932.3$ million) over a comparable time frame (this, however, does not take inflation into account, and does not trace from where the funding was sourced).

${ }^{6}$ Further national statements and policies on languages were devised, such as the 'National Statement and Plan for Languages Education in Australian Schools 2005-2008' (MCEETYA 2005) and the 'Australia in the Asian Century - White Paper' (Commonwealth of Australia 2012).

${ }^{7}$ The then Minister for Education who had initiated the inquiry into 'Teaching reading' (Dr Brendan Nelson) recently observed that 'anybody with more than a passing interest in teaching reading would regret that governments on both sides of politics had failed to implement the Rowe report' (Ferrari, 2012).

${ }^{8}$ In addition to the 'reward payments' to states and territories as laid out in COAG (2008), a current statebased example of this is Queensland's Great Results Guarantee (QDETE 2014), which requires all state schools to enter into an agreement (the 'Guarantee') under which schools will be accountable for improving student performance. Student performance is of course assessed based on achieved NAPLAN results.

${ }^{9}$ The data is still not appropriately disaggregated (ACTA 2013) and thus the test cannot inform on minoritylanguage speaking children's performance, notwithstanding the Senate report's majority recommendation 'that ACARA analyse and report publicly on how NAPLAN tests are serving different groups of Language Background Other Than English (LBOTE) students' (SRCEEWR, 2010: xi), which has apparently not been implemented properly.

${ }^{10}$ Chiro (2014) notes a similar retreat from multicultural policies in a number of Western democracies.

${ }^{11} \mathrm{~A}$ recent clear expression of this view is the speech by the now Australian Minister for Social Services, Scott Morrison, at the Menzies Centre for Australian Studies in London in January 2013. There, he argued for a 'post multiculturalism agenda' and recognition of the 'supremacy of Australian values, [and] the primacy of the English language' (Morrison, 2013). This thesis has also been put forward by studies in areas apart from literacy, such as, for instance, Hage (1998) and Martín (2008). Although in this paper we concentrate on the languages of migrants and refugees, further evidence comes from the treatment of Australia's First Peoples. One obvious example is the government withdrawal of the bilingual programs in the Northern Territory in 2008, with all its ramifications (cf. Devlin, 2009; Dickson, 2012a, b; Murphy, 2012). As this is a complex and problematic issue in itself, we do not take it up in this paper.

${ }^{12}$ We ourselves are working on a pilot study that investigates whether children can self-direct their literacy development in their minority language by playing online games in that language, thus bypassing some of the challenges posed by the wide range of languages spoken in Australia (Eisenchlas et al., in preparation). 